\title{
Sosialisasi Tanggap Darurat Dan Keselamatan Bagi Masyarakat Daerah Rawan Gempa
}

\author{
Annisa Fitria Edriani ${ }^{1^{*}}$, Lindung Zalbuin Mase $^{2}$, Besperi ${ }^{3}$ \\ 1,2,3Universitas Bengkulu \\ ${ }^{*}$ Corresponding author \\ E-mail: annisa.fe@unib.ac.id (Annisa Fitria Edriani)*
}

\section{Article History:}

Received: $30-8-2020$

Revised: $28-9-2020$

Accepted: 1-10-2020
Keywords:
Abstract: Melihat masifnya kerugian yang diderita manusia akibat gempa bumi, maka peningkatan kualitas infrastruktur semakin intensif dilakukan. Peningkatan tersebut dilakukan dengan penelitian-penelitian yang dilakukan demi meningkatkan ketahanannya terhadap gempa, seperti penemuan-penemuan material dan metode konstruksi alternatif. Gencarnya peningkatan ketahanan bangangun-bangunan ini, sayangnya kurang diimbangi dengan peningkatan pemahaman masyarakat terhadap bencana gempa bumi dan sikap tanggap dalam menghadapi bencana gempa bumi. Provinsi Bengkulu, sebagai wilayah yang mengalami gempa bumi perlu mempersiapkan warganya dengan pengetahuan dalam menghadapi gempa bumi. Kejadian gempa bumi pada tahun 2007 ternyata masih menimbulkan trauma bagi masyarakat Provinsi Bengkulu. Tim Pengabdian Pada Masyarakat Program Studi Teknik Sipil, Fakultas Teknik, Universitas Bengkulu, memilih SMA Negeri 1 Kabupaten Seluma dengan sasaran kegiatan ini adalah siswa, guru, dan pengguna gedung sekolah lainnya. Kegiatan ini diharapkan dapat meningkatkan kiprah tim pengabdian masyarakat dari Universitas Bengkulu di bidang mitigasi bencana serta meningkatkan pemahaman mengenai gempa bumi dan kesiapsiagaan masyarakat menghadapi gempa bumi.

Gempa Bumi, Mitigasi Bencana, Tanggap Darurat, Keselamatan Menghadapi Gempa Bumi 


\section{Pendahuluan}

Teori lempeng tektonik berasal dari teori pergeseran benua dan penyebaran dasar laut. Gempa bumi digunakan sebagai salah satu gejala gerakan tektonik aktif (Scholz, 1990). Teori lempeng tektonik memberikan penjelasan geologis sederhana dan umum untuk batas lempeng atau gempa antar-lempeng, yang berkontribusi $95 \%$ dari pelepasan energi seismik di seluruh dunia (EInashai dan Di Sarno, 2015). Kerak bumi terdiri dari lempengan-lempengan yang kerap saling bergesekan lalu menghasilkan akumulasi energi. Pelepasan energi secara tiba-tiba kemudian menyebabkan gempa bumi tektonik (Banerjee, dkk, 2019). Gempa yang disebabkan pergerakan magma pada aktivitas gunung api disebut gempa vulkanik. Gempa tektonik biasanya berkekuatan besar dan merusak, sedangkan gempa vulkanik biasanya berkekuatan kecil (Natawidjaja, 2008).

Di Kairo, pada tahun 1992, terjadi gempa bumi yang relatif kecil. Meski begitu, gempa itu menewaskan 545 orang, melukai 6.500 orang, membuat 50.000 orang kehilangan tempat tinggal, serta menghancurkan 350 bangunan dan merusak 9.000 bangunan lainnya, termasuk 350 sekolah, 216 masjid (bagian atas salah satu menara al-Azhar runtuh) dan monumen kuno seperti Piramida Besar di Giza, dimana sebuah balok besar berguling ke tanah (Robinson, 2013). Salah satu alasan tingginya korban jiwa adalah bahwa Kairo belum mengalami gempa bumi setelah tahun 1847. Hal ini menyebabkan kurangnya kewaspadaan pemerintah dan masyarakat terhadap bahaya gempa bumi.

Indonesia kerap mengalami gempa karena posisinya yang berada pada Ring of Fire. Indonesia berada pada zona subduksi, yaitu daerah dimana terjadi tumbukan antara dua buah lempeng (Zuhdi, dkk, 2019). Gempa-gempa dahsyat di seluruh dunia bertanggung jawab atas hilangnya nyawa, korban luka-luka dan kerusakan infrastruktur. Melihat masifnya kerugian yang diderita manusia akibat gempa bumi, maka peningkatan kualitas infrastruktur semakin intensif dilakukan. Peningkatan tersebut dilakukan dengan penelitian-penelitian yang dilakukan demi meningkatkan ketahanannya terhadap gempa, seperti penemuan-penemuan material dan metode konstruksi alternatif.

Gencarnya peningkatan ketahanan bangangun-bangunan ini, sayangnya kurang diimbangi dengan peningkatan pemahaman masyarakat terhadap bencana gempa bumi dan sikap tanggap dalam menghadapi bencana gempa bumi. Provinsi Bengkulu, sebagai wilayah yang mengalami gempa bumi perlu mempersiapkan warganya dengan pengetahuan dalam menghadapi gempa bumi. Kejadian gempa bumi pada tahun 2007 ternyata masih menimbulkan trauma bagi masyarakat Provinsi Bengkulu. Trauma ini kerap menimbulkan kepanikan yang luar biasa sehingga menyebabkan terjatuh dari tangga, menabrak sesuatu, kebakaran, dan lain sebagainya dalam usaha penyelamatan diri ketika terjadi gempa bumi.

Meminimalkan risiko yang timbul dari bencana gempa bumi meliputi beberapa hal, yaitu tindakan sebelum kejadian, tindakan saat peristiwa dan tindakan setelah kejadian (Ibrahim dan Sumunar, 2019). 
a. Sebelum Kejadian: Sebelum bencana gempa bumi perlu dipersiapkan dan pengetahuan tentang bencana. Hal ini dimaksudkan untuk menumbuhkan pemahaman dan kesiapsiagaan dalam menangani bencana sehingga kerugian dan korban diperkirakan akan berkurang

b. Saat Kejadian: Ketika bencana gempa bumi perlu diambil langkah-langkah yang bertujuan untuk menyelamatkan diri. Hal tersebut sangat penting untuk mengurangi korban karena bencana.

Menurut Sarwidi (2005), upaya mengurangi dampak bencana gempa bumi antara lain:

a. Pembuatan zonasi gempa,

b. Pembuatan peraturan mengenai bangunan tahan gempa serta melakukan pengawasan terhadap pelaksanaanya

c. Meningkatkan kewaspadaan masyarakat melalui program-program sosialisasi,sehingga masyarakat dapat mengantisipasi bencana gempa bumi.

Kesiapsiagaan adalah siklus perencanaan, pengorganisasian, pelatihan, pelengkap, latihan, evaluasi dan pengambilan tindakan korektif yang berkesinambungan. Pengabdian ini dilakukan demi meningkatkan kesiapsiagaan gempa bumi di sekolah-sekolah di daerah yang rawan gempa bumi. Tim Pengabdian Pada Masyarakat Program Studi Teknik Sipil, Fakultas Teknik, Universitas Bengkulu, memilih SMA Negeri 1 Kabupaten Seluma dengan sasaran kegiatan ini adalah siswa, guru, dan pengguna gedung sekolah lainnya. Kegiatan ini diharapkan dapat meningkatkan kiprah tim pengabdian masyarakat dari Universitas Bengkulu di bidang mitigasi bencana serta meningkatkan pemahaman mengenai gempa bumi dan kesiapsiagaan masyarakat menghadapi gempa bumi.

\section{Metode}

Kegiatan PPM dilaksanakan di SMA Negeri 1 Seluma yang terletak di Jl. Bengkulu-Tais km.61 Tais, Lubuk Kebur, Kecamatan Seluma, Kabupaten Seluma, Provinsi Bengkulu. Lokasi ditempuh dalam waktu 1,5 jam menggunakan jalur darat dari Kota Bengkulu. Sasaran kegiatan ini adalah warga SMA Negeri 1 Seluma yang terdiri atas siswa dan guru. Jumlah peserta sosialisasi sebanyak 24 orang, yang terdiri atas 22 siswa dan 2 guru. Kegiatan ini ditujukan bagi siswa SMA Negeri 1 Seluma mengingat saat kejadian gempa Bengkulu-Mentawai 2007 daerah ini merupakan salah satu daerah terdampak. Tim PPM memutuskan untuk melaksanakan sosialisasi di tempat ini dikarenakan pentingnya bekal pengetahuan anak-anak tersebut dalam menghadapi gempa bumi agar mereka dapat menyelamatkan diri. Strategi yang digunakan adalah dengan upaya edukatif berupa penyampaian materi mengenai gempa bumi, cara mempersiapkan diri menghadapi gempa bumi, serta cara menyelamatkan diri saat kejadian bencana gempa bumi. Diharapkan siswa SMA Negeri 1 Seluma memahami materi yang diberikan serta dapat menerapkannya dan menyampaikan pengetahuan tersebut kepada siswa 
lainnya, baik di SMA Negeri 1 Seluma maupun di sekolah-sekolah lainnya.

\section{Hasil}

Sebelum kegiatan PPM dilaksanakan, Ketua Pelaksana Kegiatan PPM mencoba memetakan tingkat pengetahuan calon peserta mengenai materi yang akan disampaikan. Melalui proses tanya-jawab singkat dengan Kepala Sekolah SMA Negeri 1 Seluma, diketahui bahwa calon peserta kegiatan belum pernah mengikuti kegiatan serupa sebelumnya. Materi mengenai gempa bumi pernah diberikan pada salah satu mata pelajaran, namun masih sangat minim dan tidak mencakup cara mempersiapkan diri serta menyelamatkan diri ketika bencana gempa bumi terjadi. Kegiatan penyampaian materi dilaksanakan pada tanggal 29 September 2019 di Ruang Aula SMA Negeri 1 Seluma. Acara ini dihadiri oleh Kepala Sekolah SMA Negeri 1 Seluma, beberapa guru SMA Negeri 1 Seluma, dan siswa-siswa SMA Negeri 1 Seluma. Kegiatan PPM dilaksanakan dengan penyampaian materi mengenai gempa bumi, cara mempersiapkan diri menghadapi gempa bumi, serta cara evakuasi pada saat gempa bumi terjadi. Setelah pemaparan materi, peserta kegiatan diberi kesempatan untuk memberikan pertanyaan dan berdiskusi dengan pemateri dan antar-peserta.

Tim pemateri terdiri atas Annisa Fitria Edriani, M.EngSt, Lindung Zalbuin Mase, Ph.D, dan Besperi, M.T. Pemateri memulai pemaparan dengan menarik minat peserta dengan menunjukkan video berbagai kejadian gempa bumi di dunia. Materi kemudian dilanjutkan dengan materi penyebab gempa, dan seterusnya. Berbagai gambar, video, serta cerita menarik ditampilkan sebagai pendukung paparan. Peserta yang mayoritas adalah siswa SMA Negeri 1 Seluma merespon kegiatan dengan sangat antusias. Para siswa memperhatikan dengan sangat serius dan fokus. Interaksi antara pemateri dan peserta terlihat cukup interaktif.

Setelah penyajian materi, maka kegiatan selanjutnya adalah kegiatan tanya-jawab antara pemateri dan peserta. Pertanyaan yang berhasil dihimpun di antaranya adalah sebagai berikut:

1. Sudah adakah teknologi untuk memprediksi gempa bumi secara akurat?

2. Adakah tanda-tanda akan terjadinya gempa bumi?

3. Bagaimana memastikan gedung sekolah atau rumah aman untuk dimasuki setelah gempa terjadi?

4. Haruskah mengungsi ketika gempa terjadi?

5. Siapa saja yang bisa dimintai informasi saat gempa bumi terjadi?

Pertanyaan-pertanyaan tersebut selanjutnya dijawab oleh pemateri, sebagai berikut:

1. Waktu kejadian gempa bumi tidak dapat diprediksi secara akurat. Hal tersebut dikarenakan lempeng bumi terus bergerak dan tidak diketahui kapan terjadinya pelepasan energi. Pergerakan dan pergeseran lempeng selalu dipantau oleh para ahli di seluruh dunia sehingga ahli geologi perkiraan kasar kapan potensi gempa terjadi serta potensi kekuatan gempa tersebut. Namun, peramalan waktu pasti kapan gempa akan terjadi tetap 
tidak dapat dilakukan.

2. Tanda-tanda akan terjadinya gempa bumi dapat dilihat dari hasil pencatatan pergerakan dan pergeseran lempeng. Terjadinya gempa dengan intensitas tinggi biasanya didahului oleh peningkatan aktivitas pergerakan dan pergeseran lempeng untuk gempa tektonik. Untuk gempa vulkanik, maka akan ada peningkatan aktivitas gunung berapi.

3. Cari kerusakan pada elemen struktur bangunan seperti pondasi, kolom, dan balok. Jika ditemukan kerusakan maka sebaiknya hindari masuk ke dalam sekolah/rumah untuk mengantisipasi terjadinya gempa susulan. Jika tidak yakin, maka cari ahli teknik sipil (bisa dari perwakilan pemerintah yang datang setelah gempa terjadi) dan tanyakan keamanan sekolah/rumah untuk dimasuki.

4. Jika tidak yakin apakah gempa akan disusul tsunami atau apakah sekolah/rumah aman untuk ditempati, maka sebaiknya mengungsi saja sampai informasi mengenai potensi tsunami dan gempa susulan diperoleh.

5. Biasanya akan ada perwakilan pemerintah, polisi, tentara, dan tenaga kesehatan yang akan mendatangi korban gempa bumi. Mereka bisa dijadikan sumber informasi yang terpercaya.

Melihat pertanyaan yang timbul dalam kegiatan diskusi, terlihat bahwa pemahaman masyarakat mengenai mitigasi bencana gempa merupakan hal yang penting dan perlu semakin ditingkatkan. Keberhasilan sosialisasi ini disajikan dalam matriks keberhasilan yang tampak pada Tabel 1.

Tabel 1

Matriks Indikator Pencapaian

\begin{tabular}{|c|c|c|c|c|}
\hline $\begin{array}{l}\text { Tahap } \\
\text { Kegiatan }\end{array}$ & $\begin{array}{l}\text { Waktu } \\
\text { Evaluasi }\end{array}$ & $\begin{array}{l}\text { Indikator } \\
\text { Pencapaian }\end{array}$ & $\begin{array}{l}\text { Tolak Ukur } \\
\text { Keberhasilan }\end{array}$ & $\begin{array}{c}\text { Tercapai/ } \\
\text { Tidak }\end{array}$ \\
\hline $\begin{array}{l}\text { Penyampaia } \\
\text { n Materi }\end{array}$ & $\begin{array}{l}\text { Setelah } \\
\text { penyampaian } \\
\text { materi }\end{array}$ & $\begin{array}{l}\text { a. Peserta } \\
\text { kegiatan } \\
\text { memahami } \\
\text { tentang } \\
\text { pengertian } \\
\text { gempa, } \\
\text { penyebab } \\
\text { gempa, dan } \\
\text { skala } \\
\text { pengukuran } \\
\text { gempa bumi } \\
\text { b. Peserta } \\
\text { kegiatan } \\
\text { mengetahui } \\
\text { cara } \\
\text { menyelamatkan }\end{array}$ & $\begin{array}{l}\text { a. Peserta dapat } \\
\text { memberikan } \\
\text { respons yang } \\
\text { tepat ketika } \\
\text { diberikan } \\
\text { pertanyaan oleh } \\
\text { pemateri } \\
\text { b. Peserta } \\
\text { menunjukkan } \\
\text { minat untuk } \\
\text { berdiskusi dan } \\
\text { memberikan } \\
\text { pertanyaan } \\
\text { kepada } \\
\text { pemateri }\end{array}$ & Tercapai \\
\hline
\end{tabular}




\begin{tabular}{|c|c|c|c|c|}
\hline & & $\begin{array}{l}\text { diri yang aman } \\
\text { saat kejadian } \\
\text { bencana gempa } \\
\text { bumi. }\end{array}$ & & \\
\hline $\begin{array}{l}\text { Tanya-Jawa } \\
\text { b }\end{array}$ & $\begin{array}{l}\text { Setelah sesi } \\
\text { tanya-jawab }\end{array}$ & $\begin{array}{l}\text { Peserta dan } \\
\text { pemateri } \\
\text { melakukan diskusi } \\
\text { terkait materi yang } \\
\text { diberikan }\end{array}$ & $\begin{array}{l}\text { a. Peserta } \\
\text { memberikan } \\
\text { pertanyaan-pert } \\
\text { anyaan terkait } \\
\text { materi } \\
\text { b. Pemateri dapat } \\
\text { memberikan } \\
\text { jawaban atas } \\
\text { pertanyaan } \\
\text { yang diberikan }\end{array}$ & Tercapai \\
\hline
\end{tabular}

\section{Diskusi}

Dengan berbagai keterbatasan yang dimiliki pelaksana kegiatan, tentunya kegiatan ini juga memiliki keterbatasan dalam jumlah peserta kegiatan dan juga waktu yang tersedia untuk pemaparan materi. Kegiatan ini menekankan pada komitmen peserta untuk menerapkan pemahaman yang diperoleh. Peserta memberikan pernyataan bahwa mereka berkomitmen dalam menyebarluaskan informasi dan ilmu yang diperoleh melalui kegiatan ini kepada keluarga dan siswa lainnya. Diharapkan komitmen tersebut dapat terus terlaksana. Pelaksana kegiatan tentunya merencanakan keberlanjutan dari kegiatan sosialisasi. Adanya keberlanjutan akan memastikan bahwa ilmu yang telah diberikan pemateri dapat terus dikembangkan dan terus di reinforce. Kedepannya kegiatan ini akan diikuti dengan kegiatan-kegiatan lanjutan yang akan terus berkembang dan meng-reinforce materi yang telah diberikan. Rencana keberlanjutan dari sosialisasi ini dapat dilihat dari bagan yang dapat dilihat pada Gambar 1.

\section{Kesimpulan}

Pengabdian Kepada Masyarakat ini memiliki beberapa kesimpulan, diantaranya yaitu:

1. Sebelum pelaksanaan kegiatan ini, pemahaman warga SMA Negeri 1 Seluma mengenai gempa bumi serta cara mempersiapkan dan menyelamatkan diri pada bencana gempa bumi masih sangat terbatas.

2. Kegiatan PPM ini berusaha meningkatkan pemahaman warga SMA Negeri 1 Seluma mengenai gempa bumi serta cara mempersiapkan dan menyelamatkan diri pada bencana gempa bumi.

3. Berdasarkan evaluasi mandiri yang dilakukan pelaksana kegiatan, setelah kegiatan PPM dilakukan pemahaman warga SMA Negeri 1 Seluma mengenai gempa bumi serta cara mempersiapkan dan menyelamatkan diri 
pada bencana gempa bumi meningkat.

4. LPPM UNIB telah berperan dalam usaha mitigasi bencana gempa di Kabupaten Seluma. Peran LPPM UNIB di masa yang akan datang diharapkan akan semakin besar melalui beberapa rencana lanjutan yang direncanakan penulis.

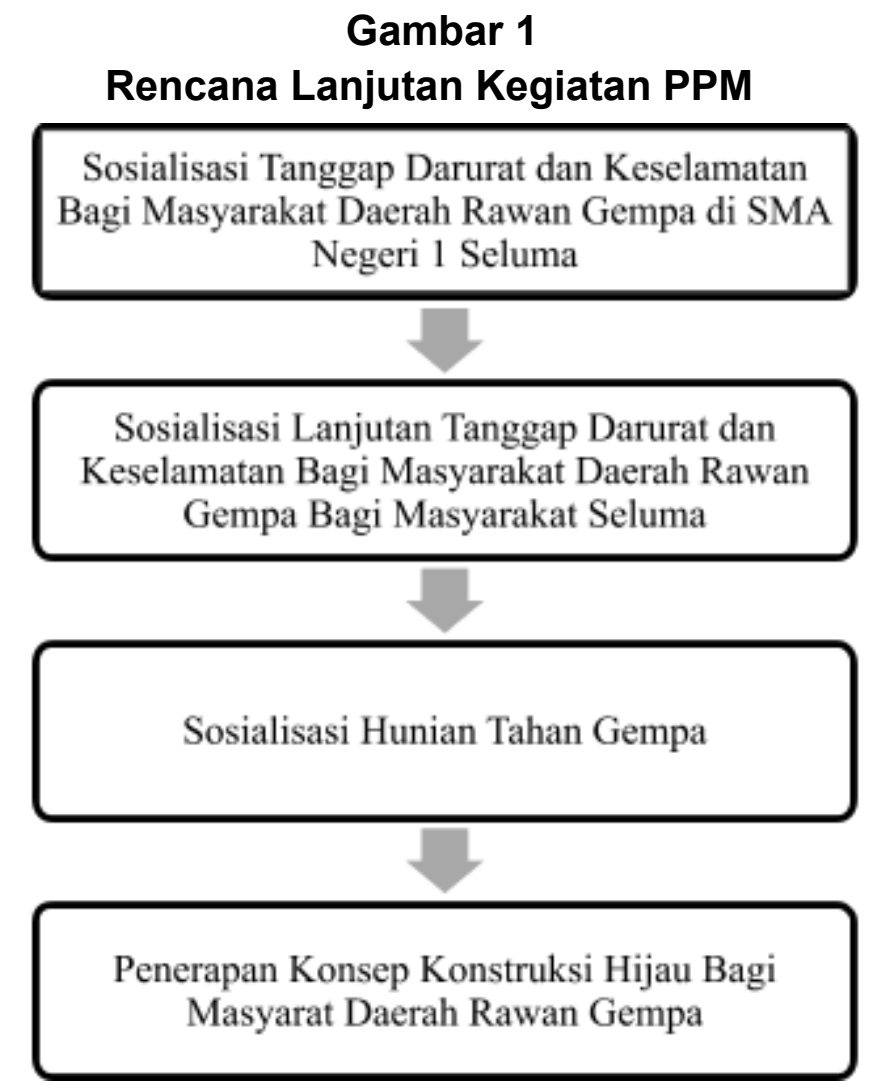

\section{Pengakuan/Acknowledgements}

Tim PPM mengucapkan terima kasih kepada kepala sekolah, guru, serta siswa SMA Negeri 1 Kabupaten Seluma yang telah terlibat dalam kegiatan pengabdian ini.

\section{Daftar Referensi}

Banerjee, R., Gangrade, B. K., Bandyopadhyay, S., \& Reddy, G. R. 2019. Introduction to Earthquakes. In Textbook of Seismic Design (pp. 1-28). Springer, Singapore.

Elnashai, A.S. dan Di Sarno, L., 2015. Fundamentals of earthquake engineering: from source to fragility. John Wiley \& Sons.

Ibrahim, Y. and Sumunar, D.R.S., 2019, June. Analysis of Earthquake Resistant House Characteristics as Optimization of Earthquake Victims. In IOP Conference Series: Earth and Environmental Science (Vol. 271, No. 1, p. 012036). IOP Publishing. 
Natawidjaya, D.H., 2008, Pedoman Analisis Bahaya, dan Risiko Bencana Gempa Bumi, Enterim Report Term I untuk BNPB.

Robinson, A., 2013. Earthquake: Nature and Culture. Reaktion Books.

Scholz, C. H. (1990). The Mechanics of Earthquakes and Faulting. Cambridge University Press, Cambridge.

Sarwidi, S., 2005. Mitigasi Gempa Mengurangi Korban Dan Kehancuran Akibat Goncangan Dan Tsunami. Jurnal Fakultas Hukum UII, (56), pp.115-120.

Zuhdi, M., Makhrus, M., Sutrio, S. and Wahyudi, W., 2019. Sosialisasi Tentang Mitigasi Bencana Tsunami dan Gempa Lombok Di Jempong Baru, Sekarbela, Mataram. Jurnal Pengabdian Magister Pendidikan IPA, 2(1). 